\title{
Financial Credit in Agricultural Development in Côte D'ivoire
}

\author{
N'GORAN Koffi Celestin (Corresponding Author) \\ Department of Economics, University Peleforo Gon Coulibaly of Korhogo, Republic of Cote \\ d'Ivoire
}

Received: August 8, 2021 Accepted: August 22, 2021 Published: September 3, 2021

doi:10.5296/jas.v9i3.18984

URL: https://doi.org/10.5296/jas.v9i3.18984

\begin{abstract}
Agriculture has long been Côte d'Ivoire's main source of export income and the first largest sector providing employment. For several decades, Ivorian agriculture remained unmodernized. The modernization of agriculture requires both public and private funding. Despite some efforts, financing of agriculture is not effective in Côte d'Ivoire due to the lack of real commitment from the private sector and commercial banks. The results showed that in the long-term agricultural credit and other variables have a positive and significant influence on agricultural added value. It is therefore recommended to increase agricultural credit and extend it to small producers.
\end{abstract}

Keywords: agricultural credit, agricultural production, reducing poverty

\section{Introduction}

The Ivorian economy has been performing remarkably well since the end of 2011. With a GDP growth rate of $-4.4 \%$ in 2011 and $10.7 \%$ in 2012, it rose to $9.2 \%$ in $2015 ; 8.8 \%$ in 2016 and $8.1 \%$ in 2017 (BCEAO Statistical Year, 2017). Between 2012 and 2015, Côte d'Ivoire experienced an average annual GDP growth of $9 \%$ and in 2016 the country was among the world's top 5 in terms of rapid growth thanks to a GDP growth of $7.5 \%$. Thanks to these impressive growth figures, Côte d'Ivoire became the world's 94th largest economy in 2016 with a GDP of USD 35.5 billion, an amount destined to grow strongly according to the IMF (Belgian Foreign Trade Agency 2017). The country owes these performances, to the improving of the security climate that restores investor confidence, to the improving of the business climate through the establishment of an investment-facilitating body, the borrowing with international financial institutions but also and above all with agriculture, the mainstay of its economic development.

Like many countries in Sub-Saharan Africa, agriculture plays a prominent role in the Ivorian economy. In $1960,87.5 \%$ of the population lived in rural areas, then $72 \%$ in 1970 and $66 \%$ 
in 1975 (Abdoulaye Sawadogo (1974)). Today, with the rapid urbanization, the share of the rural population has declined considerably. According to Cécile Lapenu (2007) in the 1960s and 1970s, financing for the rural and agricultural sector was based on strong state intervention, based on state-owned development banks and a subsidized credit supply developed as an "input" among others, for agricultural production. The State, the main financier and investor in the agricultural sector, will significantly reduce its investments in this sector leaving agricultural development solely at the account of agricultural producers and cooperatives. With difficult access to agricultural credit and a low attractiveness of the agricultural sector to national and international private investment, agricultural development is confined only to the extension of crops and the use of the few plant protection products that are very ineffective. Ivorian agriculture remains poorly modernized and the use of technology for Ivorian agriculture contributes to a $22.3 \%$ of GDP $(2013$, WB) and accounts for $47 \%$ of the country's total exports in 2013 (62\% excluding oil), it accounts for $46 \%$ of the the country's labour force and is a source of income for two-thirds of a population with $49.7 \%$ rural population (census 2014) (French Ministry of Agriculture, Agri-Food and Forestry). However, from the perspective of Côte d'Ivoire's emergence and economic development, agricultural development is still relevant today. It can help eradicate poverty, reduce unemployment through job creation, and ensure food security. The issue of agricultural financing in Côte d'Ivoire deserves special attention because agricultural financing remains a major constraint (PND 2012-2015). In such a context, we think it makes sense to analyse the impact of the financial sector on agricultural development.

The purpose of this article is to define development actions that are essential for reducing the incidence of poverty at the national and rural levels, based on economic growth analysis in general, and of the agricultural sector in particular. The rest of paper is divided as follow. Section two highlights the literature review, the model specification and data sources are exploring in part three. The section four deals with the empirical results and interpretation, then the last section concludes.

\section{Literature Review}

\subsection{Theoretical Literature Review}

Agricultural financing and agricultural credit are sometimes used in a common sense to designate the fund allocated to the agricultural sector for its development. According to Hopkin et al, agricultural finance is the means of acquiring and controlling assets, owning the cash payment or borrowing, leasing. Through agricultural credit, farmers obtain funds from financial structures to obtain means of production and improve their productivity. Agricultural development is therefore a pillar of poverty eradication and economic development. The National Agricultural Investment Programme was implemented in 2012 by the Ivorian State in partnership with the international development community in the context of agricultural development. Investment requirements were estimated at 3.05 billion euros or 2003 billion CFA francs. Funding intentions estimated at 3.1 billion euros (2041 billion CFA francs) exceeded needs. It aims for agricultural growth of around 9\%per year, food security to lift 6 to 7 million people out of food insecurity, poverty reduction from $50 \%$ to $16 \%$ until 
2020 , the creation of 2,400,000 jobs, local transformation of $50 \%$ of agricultural products. Faced with the low agricultural financing of commercial banks the State, concerned with agricultural development, has set up agricultural banks. They were responsible for giving credit to farmers for their production. The goal has always been to give credit to producers to increase their agricultural yields and improve the quality of products.

The relationship between financial development and economic growth remains a topic of interest for several theoretical and empirical studies (Pavlos Stamatiou and Nikolaos Dritsakis 2018). While some authors advocate the assumption of financial neutrality in the economy, it is worth noting that several theories are unanimous about the key role of finance in economic growth. According to Olabanji Olukayode and Henry Okodua (2013), several leading economists advocate for the positive role of finance in the economy. For the latters, financial deepening through the growth of savings, and investment cause economic growth. In contrast, for some economists such as Lucas (1988) and Stern (1989), it is economic growth that favours financial development, not the inverse. For J. M. Keynes (1936), the financial sector can contribute to economic growth through the interest rate. In fact, a fall of the interest rate as a result of an increase in the money supply favours investment and at the same time leads to an increase in production, employment, hence growth and economic development. Goldsmith (1969) focuses his argument on the role of financial markets in favour of the positive link between finance and economic growth. It argues that the development of local financial markets positively affects economic growth through the efficiency of capital accumulation (or increased marginal capital productivity). In the early 1990s, writings on endogenous growth highlighted the role of finance in long-term economic growth. These studies show that endogenous growth could influence economic growth through financial development by increasing savings and return on investment (Bencivenga -Smith 1991). Recently Muhammad and Lean (2011) have argued that a well-established and well-developed financial system increases the efficiency and effectiveness of financial institutions and drives innovation in the financial sector. This results in technical progress, reduced information costs and the profitability of investments. Joan Robinson (1952) is the leader of the antithesis of the positive role of finance in the economy. According to these authors, the ratio of money supply to nominal GDP is the opposite of the speed of movement of the currency. Thus, a positive correlation between financial development and GDP can come from the decrease in the speed of money circulation. In this case the positive link between financial development and real GDP per capital may reflect an elasticity of demand for money relative to income above one. Therefore, through demand for money, the sense of causality starts from real GDP towards financial development. Lucas (1988) considers the relationship between finance and growth to be negligible. For him, economists have overestimated the role of finance in economic growth.

R. Rajan and L. Zingales (1998) consider that the relationship between the two spheres may be attributable to few factors that are not related to a causal relationship as such. First, financial development and economic growth may depend on common omitted variables, such as the propensity to save households in the economy. Thus, since endogenous savings affect the long-term growth rate of the economy, growth and initial development are to be expected 
to be correlated. Second, financial development, estimated by the volume of distributed credit and the size of the financial market, allows us to predict the level of economic growth simply, because financial markets can anticipate growth Future. Indeed, the financial market provides an idea of growth opportunities, while financial institutions lend more when they consider that the economy will go through a period of expansion. Financial development is a simple indicator of the health of the economy rather than a causal factor (Samouel Béji 2009). Akinlo and Egbetunde (2010) believe that finance has a negative impact on economic growth. However, some authors point to the relativity of the role of finance in economic growth. According to these authors, finance can have both a negative and a positive effect on economic growth. In addition to traditional theories, there are Boserup's theory and Malthus's theory of agricultural development. Vernon W. Ruttan and Yujiro Hayani (1970) distinguish four general approaches to agricultural development: the conservation model, the urban industry impact model, the diffusion model and the massive agricultural input financing model. More recently, Udemezue J.C and Osegbue (2018) have found five general models in the literature on agricultural development. The inadequacy of policies based on previous models leads to the establishment of another model: the massive financing model in agricultural inputs. This model stipulates that the transition from traditional to modern agriculture, a source of economic growth, requires a massive investment for modernization, financing of producers in inputs in poor countries. The link between agricultural credit and agricultural growth has been the subject of many writings. According to Muhammad Ibal, Munir Ahmad and Kalbe Abbas (2003), the three main factors contributing to agricultural development are: the use of agricultural inputs, technological change and effective techniques. Agricultural credit appears to be a necessity for the acquisition of modern technologies, the use of fertilizers, the diversification of crops. Akpaeti (2015) argues that the physical factors of agricultural production commonly used are land, labour, financial capital, management and water resources. Technological and efficiency change stems from reforms in the financial sector. These reforms are aimed at the effective and efficient mobilization of funds for the agricultural sector. The increase in agricultural productivity is therefore the result of capital inflow to the agricultural sector in order to improve technology and efficiency. Financial sector reform policies are boosting investment and growth in agriculture (Akpaeti 2013). According to Zuberi (1989), for the financial sector to have an impact on agricultural development, the provided credit must be used to finance new seeds and varieties of crops, fertilizer. Farmers need short-term credits to get water, new seed varieties, fertilizer and energy. Medium and long-term credit is used for the improvement of the land, levelling, earthmoving (Qazi Muhammad Adnan Hye and Shahida Wizarat (2011)).

\subsection{Empirical Literature Review.}

Several empirical studies highlight the relationship between finance and economic growth. McKinnon (1973) conducted a study in Germany, Argentina, Brazil, Chile, Korea, Indonesia and Thailand after the Second World War on the link between the financial system and economic development. He concluded that financial systems that work perfectly generate economic growth. After him, some authors (Kar and Pentecost, (2000); Luintel and Khan, 1999; Murinde and Eng, 1994) have shown that several models of endogenous growth 
distinguish two pathways between financial development and growth. As financial development promotes growth, economic growth also leads to financial development. Chimobi (2010) analyzed the causal relationship between financial development, trade openness and economic growth in Nigeria for the period 1970-2005. Granger's causal results suggested that financial development affects economic growth and vice versa. Also using Granger's causal test through the cointegration and error correction model, Nwosa and Al. (2011) studied the causal relationship between development, FDI and economic growth. Their study found that financial development has a significant impact on economic growth. Rachdi and Mbarek (2011) conducted an empirical study of a sample of 10 countries, including six OECD countries and four MENA countries during 1990-2006. The purpose of this study was to analyze the causal relationship between finance and economic growth. The results showed that there is a long-term relationship between financial development and economic growth in the studied countries. Financial development and real GDP per capita are strongly and positively linked. Eslamloueyan and Sakhaei (2011) used annual data for the period 1994-2008 to test the short- and long-term causal relationship between financial development and economic growth in the Middle East. They found a bilateral causal relationship between financial development and long-term economic growth. One influences the other and vice versa. Kausal and Pathak (2015) studied the causal relationship between financial development, economic growth and trade opening in India from 1991 to 2013. The results of these authors found a positive relationship between economic growth, financial development and trade opening. Zuberi (1989) analyzed the production function in the agricultural sector in Pakistan from 1956 to 1986. The study concluded that agricultural development is highly dependent on technology. The government must facilitate the installation and operation of credit institutions to allow farmers to borrow for tools and the use of modern methods of production. Purchasing new technologies and inputs is crucial to improve productivity. Mbata's (1991) study of the impact of the supervised credit plan in Nigeria found that supervised credit enabled recipient producers to increase input utilization, have good returns and make large profits. Idress and Ibrahim (1993) showed that $75 \%$ of the 120 farmers who received agricultural credit in Kark district (Pakistan), improved their yields. They have equipped themselves with fertilizers, new tools. Rakesh Mohan (2004) in his article on the performance of agricultural credit in India showed that the agricultural credit system in India has some shortcomings such as inadequate supply of credit to small and marginal farmers, low mobilization of savings and the over-reliance on funds provided by agricultural credit providers. The study suggests that viable and strong financial institutions are needed for the construction of institutional and commercial infrastructure. Abedullah et al. (2009) revealed that the granting of credit to Pakistan, improved the income of livestock producers to more than $100 \%$ and helped to effectively reduce poverty in the concerned region. Agricultural credit plays a crucial role in agricultural development, job creation and improving the standard of living of producers. It not only improves agricultural productivity, but also contributes to the increase in the purchasing power of producers. G.C. Pande and Priyakumar (2013) found problems in Indian agriculture in their study. Their study suggests that agricultural financing by banks is an advantage for farmers who benefit from these credits 


\section{Macrothink}

\section{Model Specification, Data Sources and Methodology Applied}

\subsection{Model Specification}

Focus on the theoretical framework, our empirical investigation is based on the ecometric model. Zuberi (1989) shows that financing fixed agricultural investments has a non-significant impact on agricultural development. It is better to finance the purchase of factors such as plants and fertilizers. Of course, their financing comes through agricultural credit. The agricultural production function of Nawaz (2009) is thus written with the variable dependent on agricultural production expressed by agricultural added value. The explanatory variables are: arable land, in millions of hectares, agricultural labour in millions, credit granted by all credit institutions in millions of rupees, the amount of water available and the dummy variable.

The econometric model is as follows: $\mathrm{Yt}=f(\mathrm{Lt}, \mathrm{Lat}, \mathrm{Crt}, \mathrm{Wt}, \mathrm{Dt})+\mu_{t}$, $t=1,2,3, \ldots$ Yt: Agricultural production expressed by agricultural added value, Lt : Arable land, in millions of hectares, Lat : The agricultural workforce in millions, Crt:

Credit from all credit institutions in millions of rupees, Wt : The amount of available water,

Dt $^{\text {:: }}$ The Dummy variable for bad years (dummy $=1$ for 1974-75, 1983-84, 1992-93, and 2000-2001; for the other years $=0$ ).

The model is inspired by that of Nawaz (2009). However, given our overall objective and our specific objectives, we have made some changes. Our dependent variable is agricultural added value (in local currency) to account for agricultural development. Our explanatory variables are: Farm Credit (in dollar); agricultural employment (as a \% of total employment); agricultural land (as a \% of the territory) The basic model is as follows: $\mathrm{VAAt}=\mathrm{f}(\mathrm{CA}, \mathrm{EAt}, \mathrm{TAt})+,\mathrm{Ut}^{\prime}$. with $\mathrm{t}=1,2,3, \ldots$

Specifically, we have: LVAAt $=\beta_{0}+\beta_{1}(\mathrm{LCAt})+$ 版 $_{2}(\mathrm{EAt})+\beta_{3}(\mathrm{TAt})+\mu \mathrm{t}$ where: LVAAt': logarithm of agricultural added value (in local currency), LCA : Farm credit (in dollar), EAt : Jobs in agriculture (\% of total jobs), TAt : Farmland (\% of territory), Ut: The term of error

The overall objective of this study is to analyse and highlight the role of agricultural credit in development in Côte d'Ivoire. From this general objective arise three (3) specific objectives:

- Analyzing the short-term impact of agricultural credit on agricultural added value 
- Show the long-term impact of agricultural credit on agricultural added value

- Analyzing the impact of other determinants of agricultural development on agricultural added value

Hence, the assumptions on which our analysis is based are enumerated as:

H1: Agricultural credit from the financial sector has a positive impact on agricultural development in the short term.

H2: Agricultural credit positively impacts long-term agricultural added value

H3: Other factors underlying agricultural development have a positive impact on agricultural added value in the long term.

The above hypotheses will be tested at the 0.05 level of significance. The null hypothesis will be rejected if the probability at which the t-value is significant is less than the conventional level, otherwise, the null hypothesis will be accepted.

\subsection{Data Sources}

All of our data (farm added value, agricultural employment and agricultural land) was extracted from the World Development Indicators (WDI) database version 2017.The agricultural credit data that was taken from the FAO (Food Organization) database on the FAOSTAT website. Ivorian agriculture has long played a prominent role in Côte d'Ivoire's gross domestic product (GDP) since the country's independence. For years, the Ivorian economy remained undiversified and heavily dependent on agricultural added value. Agricultural added value grew exponentially over the 1991-2017 period, despite some slight declines, notably in 2003 and 2011. These periods are marked by political crises that have influenced agricultural production in Côte d'Ivoire. The state remains the main promoter of agricultural development. The performance of Ivorian agriculture is largely based on the various programmes and actions implemented by the State to develop agriculture. The improvement in the share of agricultural added value can also be explained by other factors such as good weather conditions, targeted government policies for growth in certain sectors such as rice and cassava (World Bank 2016). Volatility in agricultural commodity prices also influences agricultural added value and GDP.

\subsection{Methodology Applied}

In order to verify the relationship between financial sector credit and agricultural development through the share of agricultural added value (positive and significant impact of financial sector credit on agricultural added value), we will use an ARDL AutoRegressive Distributed Lag (self-regressive models with staggered or distributed delays). The ARDL model is a dynamic model that takes into account the time dynamics of a variable, namely expectations, adjustment time. It combines two large models that are the AR model and the DL model. The AR or Self-Regressive model reflects the regression of a variable on itself or on its own staggered values. It is a dynamic model of which some of its explanatory variables are the staggered dependent variable (the dependent variable is explained by its own delayed 
values).

The objective of our study is to show the impact of the financial sector on agricultural development, i.e. how domestic credit provided by the financial sector can impact agricultural added value. Our dependent variable is therefore the added value of agriculture (VAA) expressed in local currency which will be explained by the agricultural credit (CA), employment in agriculture (EA) expressed as a percentage of total employment and agricultural land (TA) expressed as a percentage of the territory.

The colinearity between the explanatory variables (at the DL model level) and the self-correlation of errors (AR models) are difficulties faced by ARDL models. We will therefore use robust estimation techniques.

\section{Empirical Results and Interpretations}

In this section, we first analyze the summary of the descriptive statistics of the different variables presented in Tables 2 and 3 bellow. Jacque-Bera statistic, Sample means, skewness, standard deviation, p-value have and kurtosis are reported. The low standard deviation of all variables (sample 1and 2) with respect to the mean is an indication of low volatility in all simple variables. As we see, we accept to reject the null hypothesis that all variables (sample 1and 2) are normally distributed from the p-values observed.

In this study, we will attempt to show the influence of explanatory variables on the dependent variable. Our dependent variable is agricultural added value (VAA) as mentioned above. We will measure agricultural development through agricultural added value. Explanatory variables are those that are likely to impact and explain the dependent variable. The main explanatory variable in our model is agricultural credit (expressed in dollars). Other explanatory variables are: agricultural employment (as a percent of total employment); agricultural land (as a percent of the territory). The following table shows the effects we hope to have. In terms of the standard deviation (Std. Dev.), we find that agricultural employment and agricultural land are more volatile in relation to agricultural added value and compared to other variables. Indeed, these variables are very sensitive to certain parameters. The political crisis has greatly influenced agricultural credit and agricultural employment.

Table I. Descriptive analysis of variables

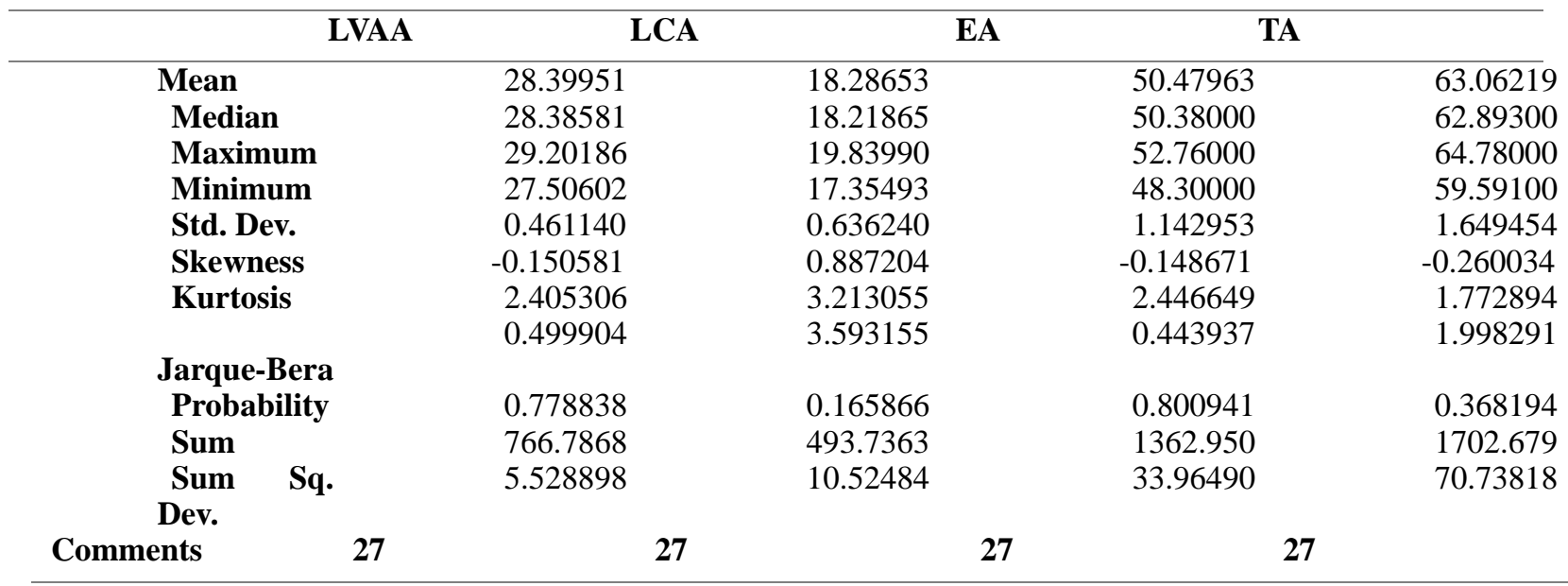


Source: Computed by the author

The Ivorian financial sector is facing some difficulties. The bank rate remains low and was of $15 \%$ in 2014, capital markets are poorly developed and do not finance the economy in Côte d'Ivoire (World Bank Report 2016). Because of the lack of confidence and guarantee, banks do not provide enough credit. Farm credit declined from 1991 to 2001 and then increased slightly from 2002 to 2009. Between 2010 and 2011, there was still a decline due to the post-election crisis in the country. The implementation of the National Agricultural Investment Plan from 2012 has increased the allocated credit to the agricultural sector.

There is a need to distinguish between the working population and the employed population. According to the National Survey on the Status of Employment and Child Labour (ENSETE 2013), the working population includes the working population for personal consumption (households, farmers working for their livelihoods), workers, unpaid training workers, the population in other forms of production work. The agricultural employed population takes into account all those who make agriculture their profession and excludes all those who practice agriculture for their livelihood. Agricultural employment includes self-employment, which accounts for $30 \%$ of total employment and includes self-employed farmers and agricultural employers, as well as agricultural wage employment, which accounts for $4 \%$ of total employment (ENSETE 2013).

The decline in agricultural employment can be explained by the phenomenon of rural exodus marked by the mass displacement of young people from the village to the city in search of a better life. However, during the years of crises, many prefer returning in the village to cultivate the land. This explains the increase in agricultural employment from 1999 to 2003 and from 2009 to 2010. Although the share of agricultural employment total employment is declining, agriculture remains the leading sector providing employment in Côte d'Ivoire with 48.32 per cent of total employment in 2017 (World Development Indicators, 2017). Agriculture in Côte d'Ivoire consumes more land due to the virtual absence of new methods and technologies. It is practiced over large spaces and often does not give the expected results. Agricultural land grew slightly between 1991 and 1996, declined from 1997 to 2003, followed by growth from 2003 to 2007 before stagnating. Since 2007, agricultural land has occupied $64.78 \%$ of the national territory (World Development Indicators, 2017). Stationarity is when a time series has its average (hope) and variance that are constant over time. When the hope and variance vary over time, the series is said to be non-stationary. To study the stationary nature of variables or not, there are several tests. We have among other things: the Dickey-Fuller Enhanced/ADF test, Phillippe Perron/PP test, Andrews and Zivot/AZ test, Ng-Perron test, KPSS, Ouliaris-Park-Perron. As part of our study, we used the ADF (Augmented Dickey-Fuller) and PP (Phillips-Perron) tests. In both tests (Dickey-Fuller Increased and Phillips-Perron), if the series are non-stationary (unit root presence) in level, we will differentiate them and do the stationarity tests again. The simplified results of the Dickey-Fuller and Phillips-Perron tests are recorded in the table below. 
Table II. Summary of unit root tests

\begin{tabular}{|c|c|c|c|c|c|}
\hline \multirow[t]{2}{*}{ Variables } & Level & \multicolumn{2}{|c|}{ First Difference } & \multicolumn{2}{|c|}{ Integration } \\
\hline & $\mathrm{ADF}$ & $\mathrm{PP}$ & $\mathrm{ADF}$ & PP & \\
\hline & t-statistics & t-statistics & t-statistics & s t-stat & tics \\
\hline LVAA & $\begin{array}{l}-2.112930 \\
(0.5151)\end{array}$ & $\begin{array}{l}-0.461064 \\
(0.8838)\end{array}$ & $\begin{array}{l}-5.078444 \\
(0.0004)\end{array}$ & $\begin{array}{c}-4.973105 \\
(0.0027)\end{array}$ & I (1) \\
\hline LCA & $\begin{array}{r}-1.803657 \\
(0.6737)\end{array}$ & $\begin{array}{r}0.379794 \\
(0.9780)\end{array}$ & $\begin{array}{l}-5.614415 \\
(0.0006)\end{array}$ & $\begin{array}{c}-5.600960 \\
(0.0006)\end{array}$ & $\mathrm{I}(1)$ \\
\hline EA & $\begin{array}{c}-1.981568 \\
(0.2925)\end{array}$ & $\begin{array}{c}-1.900493 \\
(0.3269)\end{array}$ & $\begin{array}{l}-6.176448 \\
(0.0000)\end{array}$ & $\begin{array}{l}-6.366128 \\
(0.0000)\end{array}$ & $\mathrm{I}(1)$ \\
\hline TA & $\begin{array}{l}-1.420867 \\
(0.5559)\end{array}$ & $\begin{array}{c}-1.939678 \\
(0.3100)\end{array}$ & $\begin{array}{l}-3.051525 \\
(0.0437)\end{array}$ & $\begin{array}{l}-2.822351 \\
(0.0067)\end{array}$ & I (1) \\
\hline
\end{tabular}

(.): Probability Source: Computed by the authors. The $\Delta$ denotes first-difference derivation. The asterisks $*, * *$, and $* * *$ denote statistical significance at $10 \%, 5 \%$, and $1 \%$ levels, respectively. McKinnon (1980) critical values are used for rejection of the null unit root.

All of our variables are integrated in order 1, i.e. stationary in first difference. The Granger test can be applied in this case. However, we decide to apply the cointegration of Pesaran et al. (2001) which is even more effective especially when variables are integrated in different order.

The first step is to determine the optimal lag either by the Schwarz Information Criterion (SIC) or by the Akaike Information Criterion (AIC). The second step is to use Fisher's test to test the co-integration between series. Table 3 shows us the optimal delay number. 
Table III. Optimal shift

VAR Lag Order Selection Criteria

Endogenous variables: LVAA LCA EA TA

Exogenous variables: $\mathrm{C}$

Sample:1991-2017

Included observations: 25

$\begin{array}{cllllll}\text { Lag } & \text { LogL } & \text { LR } & \text { FPE } & \text { AIC } & \text { SC } & \text { HQ } \\ \mathbf{0} & -88.52296 & \text { NA } & 0.019264 & 7.401837 & 7.596857 & 7.455927 \\ \mathbf{1} & 5.780193 & 150.8850^{*} & 3.75 \mathrm{e}-05^{*} & 1.137585^{*} & 2.112685^{*} & 1.408036^{*} \\ \mathbf{2} & 18.21611 & 15.91798 & 5.58 \mathrm{e}-05 & 1.422711 & 3.177892\end{array}$

Source: Computed by the author. The $\Delta$ denotes first-difference derivation. The asterisks *, **, and $* * *$ denote statistical significance at $10 \%, 5 \%$, and $1 \%$ levels, respectively.

* indicates lag order selected by the criterion

All the criteria (LR, FPE, AIC and HQ) shows us that the optimal delay is 1 . So we keep the number of delays 1 for this study. The estimated ARDL model is as follows:

Table IV. Estimation of the ARDL Model $(1,1,1,1)$

\begin{tabular}{|c|c|c|c|c|}
\hline \multicolumn{5}{|c|}{$\begin{array}{l}\text { Dependent Variable: LVAA } \\
\text { Model selection method: Akaike info criterion (AIC) } \\
\text { Dynamic regressors }(1 \text { lag, automatic): LCA EA TA } \\
\text { Selected Model: ARDL }(1,1,1,1)\end{array}$} \\
\hline Variable & Coefficient & $\begin{array}{l}\text { Std. } \\
\text { Frror }\end{array}$ & t-Statistic & Prob.* \\
\hline $\operatorname{LVAA}(-1)$ & 0.836898 & 0.051201 & 16.34526 & 0.0000 \\
\hline LCA & -0.068022 & 0.060694 & -1.120726 & 0.2764 \\
\hline $\operatorname{LCA}(-1)$ & 0.140644 & 0.061465 & 2.288186 & 0.0338 \\
\hline EA & 0.053998 & 0.014004 & 3.855975 & 0.0011 \\
\hline $\mathbf{E A}(-1)$ & -0.028756 & 0.017448 & -1.648113 & 0.1158 \\
\hline TA & -0.149016 & 0.040500 & -3.679378 & 0.0016 \\
\hline TA(-1) & 0.182805 & 0.041622 & 4.391977 & 0.0003 \\
\hline R-squared & 0.979503 & \multicolumn{2}{|c|}{ Mean dependent var } & 28.42963 \\
\hline $\begin{array}{l}\text { Adjusted } \\
\text { R-squared }\end{array}$ & 0.973031 & \multicolumn{2}{|c|}{ S.D. dependent var } & 0.442362 \\
\hline $\begin{array}{l}\text { S.E. } \\
\text { regression of }\end{array}$ & 0.072646 & \multicolumn{2}{|c|}{ Akaike info criterion } & -2.181624 \\
\hline $\begin{array}{l}\text { Sum squared } \\
\text { resid }\end{array}$ & 0.100272 & \multicolumn{2}{|c|}{ Schwarz criterion } & -1.842906 \\
\hline Log likelihood & 35.36112 & \multicolumn{2}{|c|}{ Hannan-Quinn criter. } & -2.084086 \\
\hline
\end{tabular}

Durbin-Watson stat

$\mathbf{2 . 4 9 7 7 6 7}$

*Note: p-values and any subsequent tests do not account for model selection

We note that the ARDL model $(1,1,1,1)$ has the lowest value of the Akaike information criterion. It is therefore the most optimal model. We then conduct validation tests of the model. In the absence of self-correlation, homoscedicity and normal error, we can conclude that our ARDL model has been well specified. 
Table V. ARDL model validation tests

\begin{tabular}{lllll}
\hline Tests & Assumptions & Values & Probability & Decision \\
& & & & \\
\hline Breusch-Godfrey & Autocorrelation & 1.509642 & 0.2350 & Lack of self-correlation of errors \\
Breusch-Pagan-Godfrey & Heteroscesce & 1.253633 & 0.3263 & Lack of heteroscesce of errors \\
Jarque-Bera & Normality & 0.095587 & 0.953330 & Normality of errors \\
Ramsey (Fisher) & Specification & 0.023454 & 0.9815 & Good specification
\end{tabular}

Source: Computed by the author

The null hypothesis is accepted in the various validation tests of the model because their probability is greater than 5\%. There is an absence of self-correlation of errors, homoscesticity of errors, normality. The stability tests of CUSUM and CUSUM-Square reveal that the model is perfectly stable. Thus, the model is well specified, stable and validated.

The cointegration test of Pesaran et al. (2001) is done with Fisher's test statistics. Co-integration is when Fisher's (F-stat) statistic is higher than the upper terminal. When it is inferior, then there is no co-integration relationship. If Fisher's statistic is between the two terminals, we cannot conclude.

Table VI. Results of the cointegration test of Pesaran et al. (2001) or terminal test

\begin{tabular}{lll}
\hline Test Statistics & Value & K \\
F-statistics & 10.75424 & 3 \\
& $\begin{array}{c}\text { Critical values of terminals } \\
\text { upper terminal } \\
\text { Level }\end{array}$ & $\begin{array}{l}\text { upper terminal } \\
\text { (I0) }\end{array}$ \\
$\mathbf{1 0 \%}$ & 2.01 & 3.1 \\
$\mathbf{5 \%}$ & 2.45 & 3.63 \\
$\mathbf{2 . 5 \%}$ & 2.87 & 4.16 \\
$\mathbf{1 \%}$ & 3.42 & 4.84 \\
\hline
\end{tabular}

Source: Computed by the author

There is a co-integration relationship between the variables in the series because the value of Fisher's statistic (10.75424) is greater than the value of the terminal above all considered levels. The long-term effects of explanatory variables (LCA, EA, TA) on the dependent variable (LVAA) can therefore be estimated. The results of the correlation between our variables can be found in the correlation matrix table below: 
Table VII. Simple correlation matrix between variables

\begin{tabular}{lllll}
\hline & LVAA & LCA & EA & TA \\
\hline LVAA & 1 & 0.6587806 & -0.643565 & 0.813046 \\
LCA & 0.6587806 & 1 & -0.407524 & 0.5923626 \\
EA & -0.643565 & -0.407524 & 1 & -0.713656 \\
TA & $\mathbf{0 . 8 1 3 0 4 6}$ & $\mathbf{0 . 5 9 2 3 6 2 6}$ & $\mathbf{- 0 . 7 1 3 6 5 6}$ & $\mathbf{1}$ \\
\hline
\end{tabular}

Source: Computed by the author

There is a likely link between variables when the degree of association exceeds 0.50 . Looking at our chart, we note that with the exception of agricultural employment, multi-facetedness can exist between agricultural added value and dependent variables. It is also possible that there is a link between agricultural credit and agricultural land $(0.5923626$ is greater than $0.50)$. The causality test will verify these claims. Granger's causal test is the one we will use to study the causality between variables. It is effective when variables are integrated in the same order.

Table VIII. Granger's causality's test

\begin{tabular}{lcc}
\hline Null Hypotheses : & F-Statistic & Prob. \\
\hline LCA does not cause LVAA & 0.60732 & 0.4437 \\
LVAA does not cause LCA & 11.6535 & 0.0024 \\
EA does not cause LVAA & 4.11551 & 0.0542 \\
LVAA does not cause EA & 5.05605 & 0.0344 \\
TA does not cause LVAA & 4.91490 & 0.0368 \\
LVAA does not cause TA & 0.08673 & 0.7710 \\
EA does not cause LCA & 3.74900 & 0.0652 \\
LCA does not cause EA & 2.64602 & 0.1174 \\
TA does not cause LCA & 3.00448 & 0.0964 \\
LCA does not cause TA & 4.80947 & 0.0387 \\
TA does not cause EA & 8.49354 & 0.0078 \\
EA does not cause TA & 4.55211 & 0.0438 \\
\hline
\end{tabular}

Source: Computed by the author

In analyzing the above table, we find that there are sometimes one-way causalities and often the causalities are two-way. Farm credit (ACA) does not cause agricultural added value, while agricultural added value causes agricultural credit. The same is true for the relationship between agricultural employment (EA) and agricultural added value (LVAA) where agricultural value-added influences agricultural employment and the reverse does not occur, agricultural land (TA) influences agricultural added value (LVAA), farm credit (LCA) 
influences agricultural land (TA). There is a causal absence between agricultural employment (EA) and agricultural credit (LCA) and a two-way causality between agricultural land (TA) and agricultural employment (EA). The two variables exert mutual influences on them (agricultural land causes agricultural employment and agricultural employment also influences agricultural land).

The results of the short- and long-term coefficient estimate are included in the table below. These results will be interpreted.

Table IX. Results of short-term coefficients

\begin{tabular}{lcccc}
\hline \multicolumn{1}{l}{ Dependante Variable: LVAA } & & & \\
Variable & Coefficient & Std. Error & t-Statistic & Prob. \\
D(LCA) & -0.068022 & 0.060694 & -1.120726 & 0.2764 \\
D(EA) & 0.053998 & 0.014004 & 3.855975 & 0.0011 \\
D(TA) & -0.149016 & 0.040500 & -3.679378 & 0.0016 \\
Coint Eq (-1) & -0.163102 & 0.051201 & -3.185496 & 0.0049 \\
\hline
\end{tabular}

Source: Computed by the author, $\mathrm{R}^{2}=0.979503$

Coint eq $=$ LVAA $-(0.4453 *$ LCA $+0.1548 * \mathrm{EA}+0.2072 * \mathrm{TA})$

Table X. Resultats of long-term coefficients

\begin{tabular}{lcccl}
\hline \multicolumn{4}{l}{ Dependante Variable: LVAA } & \\
Variable & Coefficient & Std. Error & t-Statistic & Prob. \\
LCA & 0.445258 & 0.193315 & 2.303272 & 0.0327 \\
EA & 0.154760 & 0.044598 & 3.470077 & 0.0026 \\
TA & 0.207166 & 0.059691 & 3.470628 & 0.0026 \\
\hline
\end{tabular}

Source: Computed by the author, $\mathrm{R}^{2}=0.979503$

Based on the results of the estimate, the recall force coefficient is negative and significant $(-0.163102)$. In absolute terms, its value is between 0 and 1 . Therefore, there is a mechanism for correcting errors and a long-term relationship between variables. The $\mathrm{R}^{2}$ determination coefficient and the Adjusted Determination Coefficient A- $\mathrm{R}^{2}$ are respectively 0.979503 and 0.973031 . This implies that $97.95 \%$ of the change in agricultural added value is taken into account by the variables in the model. Also, the value of the adjusted determination coefficient means that $97.30 \%$ of the change in added value is explained by the variables in our study.

The results of the short-term coefficients show that agricultural credit has a negative and not 
significant effect on agricultural added value. When agricultural credit increases by $1 \%$, agricultural added value decreases by $0.068 \%$. It can be said that the short-term impact of agricultural credit on agricultural added value is negligible. This negative result can be explained by the misallocation of agricultural credit and its management by producers. The failure of agricultural banks (BNDA and BFA) is due in part to the granting of agricultural credit to people who are not in the agricultural sector and who used this money to meet other needs. Much of the agricultural credit was not for producers. Also, there is no monitoring of the agricultural credit granted to producers who can use it for other purposes. In this context, the increase in agricultural credit cannot have a positive effect on agricultural development through agricultural added value. Sometimes credit from financial institutions whose microfinances are high interest rates. In case of a poor harvest, the income from the production will be used for reimbursement. This can discourage the producer and have effects on the production.

In addition, agricultural employment has a positive and significant influence on agricultural added value in the short term. When agricultural employment increases by $1 \%$, agricultural added value increases by $0.054 \%$. The study by Iqbal, Munir and Abbas (2003) confirms this result. These authors showed in their study that the agricultural labour force has a positive and statistically significant effect on agricultural production. Second, agricultural land has a negative and statistically significant coefficient on agricultural added value (-0.149016). An increase in agricultural land of $1 \%$ leads to a decrease in agricultural added value of $0.15 \%$. Agricultural credit has an indirect effect on the efficiency of agricultural land. Thanks to agricultural credit, fertilizers can be purchased to improve soil fertility. Thus, the short-term result of agricultural credit affects that of agricultural land, which in turn impacts production. The study of the long-term relationship will tell us whether this assertion is valid.

The results of long-term coefficients are slightly different from those of the short term. The sign of agricultural credit and agricultural land coefficients has changed. The agricultural credit ratio, which is negative in the short term, is positive and significant in the long term. In the long term, when agricultural credit increases by $1 \%$, agricultural added value also increases by $0.4453 \%$. This result is in line with that of Nawaz (2011). The author found a positive and statistically insignificant influence of agricultural credit on agricultural added value. The non-meaningful nature of agricultural credit is due to the constraints imposed on access to credit. Small producers have difficulty accessing credit. Thus, those who produce the most (individual producers) cannot access agricultural credit to improve their productivity. Agricultural credit is mainly used to purchase fertilizers, machinery or tractors, new crop varieties and sometimes agricultural land for private producers. The sign of the agricultural employment coefficient has not changed. The long-term coefficient of agricultural employment is $0.1548 \%$. It is significant (probability $=0.0026$ ) and means that for a $1 \%$ increase in agricultural employment, agricultural added value increases by $0.1548 \%$. In terms of agricultural employment, it is worth noting the interest of young people in this sector over the past two decades. This can be explained by the creation of agricultural training schools, the creation of private agricultural companies and the opening of agronomics. All these trainings improve the level of agricultural employment and, in turn, promote 
agricultural development. Finally, we note that as a result of the change in the agricultural credit coefficient, the agricultural land coefficient has also changed. If agricultural land increases by $1 \%$, agricultural value-added increases by $0.21 \%$. This coefficient is positive and significant. Agricultural credit improves the productivity of agricultural land through the purchase of fertilizers. Agricultural land in turn influences agricultural production. The stated above results allow us to verify our assumptions. Hypothesis 1 states that agricultural credit has a positive impact on short-term added value. However, the results show us that in the short term, agricultural credit has a negative impact on agricultural added value. Hypothesis 1 is therefore rejected and we conclude after our study that agricultural credit negatively and not significantly affects short-term agricultural added value in Côte d'Ivoire. Although agricultural credit negatively impacts agricultural added value in the short term, it has a positive impact on it in the long term. Also, the factors underlying agricultural development in Côte d'Ivoire have a positive impact on long-term value added. These factors are: agricultural employment and agricultural land. We have also seen through the Granger causal test that there is indeed a one-way causal relationship between the dependent variable and the other explanatory variables and sometimes between the explanatory variables themselves.

\section{Conclusion}

The agricultural credit is primarily intended for the purchase of machinery, tractors, fertilizers and new varieties of seeds and plants. Estimating short- and long-term coefficients has allowed us to detect a negative and non-significant impact of agricultural credit on agricultural added value in the short term and then a positive and significant impact in the long term. In the short term only, agricultural employment has a positive and significant influence on agricultural added value. In the long term, agricultural employment and agricultural land have a positive influence on the dependent variable. According to our study, the variables that promote agricultural development in Côte d'Ivoire are agricultural credit, agricultural employment and agricultural land.

After such a study, we would like to make policians recommendations to take decisions for agricultural development in Côte d'Ivoire. The financial sector is the engine of economic growth through investment in the various fields of activity, especially in the agricultural sector. There is a need to improve the performance of the financial sector, promote financial inclusion and raise the level of banking. Encourage commercial banks to give more credit to producers and expand credit to small producers who often do not benefit from agricultural credit. Also, in the case of borrowing, credit monitoring is necessary in order to be aware of the effective use of agricultural credit to meet the needs of agricultural production. Set up private agricultural banks of which the State can be a shareholder to support commercial banks and microfinance. Encourage agricultural Foreign Direct Investment (FDI) and encourage the private sector to set up private agricultural enterprises. Establish targeted agricultural development policies for certain consumer products such as rice to reduce imports, ensure food security and self-sufficiency. Locally transform agricultural raw materials. Local product processing ensures gains in product added value and will contribute to agricultural development. Build road infrastructure to transport products and product 
conservation infrastructure. Open more agricultural training schools and encourage young people to take an interest in agricultural employment in order to reduce unemployment.

\section{References}

Abedullah, N. et al. (2009). The role of agriculture credit in the growth of livestock sector: A case study of Faisalabad. Pakistan Veterinary Journal, 29(2), 81-84.

Adam, M. A. (2011). Financial Openness Induced Growth and Poverty Reduction. The International Journal of Applied Economics and Finance, 5(1), 75-86, https://doi.org/10.3923/ijaef.2011.75.86

Adeniran, A. O., Azeez, M. I., \& Aremu, J. A. (2016). External Debt and Economic Growth in Nigeria: A Vector Auto-Regression (Var) Approach. International Journal of Management and Commerce Innovations ISSN 2348-7585 (Online), 4(1), 706-714, Month: April 2016 September 2016.

Akinlo, A. E., \& Egbetunde, T. (2010). Financial Development and Economic Growth: The Experience of 10 Sub-Saharan African Countries Revisited. The Review of Finance and Banking, $02(1)$

17-28.

https://econpapers.repec.org/RePEc:rfb:journl:v:02:y:2010:i:1:p:017-028

Akpaeti A. J. (2013). Does financial sector reforms affect agricultural investments in Nigeria? A Cointegration and VAR Approach. International Journal of Food and Agricultural Economics, 1(2), 13-28. https://doi.org/10.22004/ag.econ.160091

Anonyme (1993). Ministère de l'Agriculture et des Ressources Animales, Plan Directeur Du Development Agricole 1992-2015

Asamoah, G. N. (2008). The Impact of the Financial Sector Reforms on Savings, Investments and Growth of Gross Domestic Product (GDP) in Ghana. International Business and Economic Research Journal, 7(10), 73-84. https://doi.org/10.19030/iber.v7i10.3302

Ayodeji, A. (2017). Capital Market Development and Economic Growth in Nigeria. Scholedge International Journal of Management \& Development, ISSN 2394-3378,04(10), 99-110. https://doi.org/10.19085/journal.sijmd041001

Banque, M. (2016). Situation économique en Côte d'ivoire.

Eslamloueyan, K., \& Sakhaei, E. (2011). The Short Run and Long Run Causality between Financial Development and Economic Growth in the Middle East. Iranian Journal of Economic Research, 16(46), 61-76.

Esso, L. J. (2010). Cointegration and Causality between Financial Development and Economic Growth: Evidence from ECOWAS Countries. Journal of Economics and International Finance, 2(3), 036-048, March 2010.

FAO, FIDA et PAM (2015), The State of Food Insecurity in the World 2015. Meeting the 2015 international hunger targets: taking stock of uneven progress, Food and Agriculture Organisation Publications, Rome. 
Foluso, A. A., \&Nicholas, M. O. (2017) The impact of financial liberalization on economic growth in sub-Saharan Africa. Cogent Economics \& Finance, 5(1), 1338851. https://doi.org/10.1080/23322039.2017.1338851

Goldsmith, R. W. (1969). Financial Structure and Development. Yale University Press, New Haven.

Hurlin, C., \& Venet, B. (2008). Financial Development and Growth: A Re-Examination using a Panel Granger Causality Test.

Idress, M., \& Ibrahim, M. (1993). Farmers' Utilization of Agricultural Credit for the adoption of improved farm practices. Journal of Rural development and administration. 25(1), 34-35.

Kar, M., \& Pentecost, E. J. (2000). Financial Development and Economic Growth in Turkey: Further Evidence on the Causality Issue. Economic Research Paper No. 00/27

Kaushal, L. A., \& Pathak, N. (2015). The Causal Relationship among Economic Growth, Financial Development and Trade Openness in Indian Economy. International Journal of Economic Perspectives, 9(2), 5-22.

King, R., \& Levine, R. (1993b). Finance, Entrepreneurship and Growth. Journal of Monetary Economics 32(1993) 513-542. North-Holland. https://doi.org/10.1016/0304-3932(93)90028-E

Lucas. R. E (1988). On the Mechanics of Economic Development, Journal of Monetary Economics, 22(1), 3-42. https://doi.org/10.1016/0304-3932(88)90168-7

Mbata, J. N. (1991). Comparative study of Supervised and non-Supervised agricultural credit Schemes. As a tool for Agricultural Development in Rivers State, Nigeria. Discovery and Innovation, 3(4), 29-35.

Muhammad, I., Munir, A, \& Kalbe, A. (2003), The Impact of Institutional Credit on Agricultural Production in Pakistan. https://doi.org/10.30541/v42i4IIpp.469-485

Nwosa, P. I., \& Agbeluyi, A. M., \& Saibu, O. M. (2011). Causal Relationships between Financial Development, Foreign Direct Investment and Economic Growth: The Case of Nigeria. International Journal of Business Administration 2(4), 93-102 https://doi.org/10.5430/ijba.v2n4p93

Okpara, G. C. (2010). The Effect of Financial Liberalization on Selected Macroeconomic Variables: Lesson from Nigeria. The International Journal of Applied Economics and Finance,

1-9.https://www.econbiz.de/Record/the-international-journal-of-applied-economics-and-finan ce/10003884031

Pagano, M. (1993). Financial Markets and Growth: An Overview. European Economic Review, 37, 613-622. https://doi.org/10.1016/0014-2921(93)90051-B

Pande, G. C., \& Priyakumar, (2013). Meeting Future credit needs of Agriculture. The Indian Banker, 1(5). 


\section{Macrothink}

Journal of Agricultural Studies

ISSN 2166-0379

2021, Vol. 9, No. 3

Pavlos, S., \& Nikolaos, D. 29 Octobre 2018 Financial Development and Economic Growth: The Case of Greek Economy. https://doi.org/10.22158/ijafs.v1n2p173

Qazi, M. A. H., \& Shahida, W. (2011). Impact of financial liberalization on agricultural growth: a case study of Pakistan. https://doi.org/10.1108/17561371111131317

Rajan, R. G., \& Zingales, L (2003b). Saving Capitalism from the Capitalists: Unleashing the Power of Financial Markets to Create Wealth and Spread Opportunity, Crown Business, New York.

Rajan. R. G., \& Zingales, L (2003a). The Great Reversals: The Politics of Financial Development in the 20th Century. Journal of Financial Economics, 69(1), 5-50. https://doi.org/10.1016/S0304-405X(03)00125-9

Rakesh, M. (2004). Agricultural credit in India: Status, Issues and future Agenda. Reserve Bank of India Bulletin

Robinson, J (1952). The Generalisation of the General Theory » dans « The Rate of Interest and Other Essays, Macmillan, London.

Samouel, B. (2009) Le développement financier pour les pays du sud de la méditerranée à l'épreuve de la mondialisation financière). https://doi.org/10.4000/regulation.7712

Schumpeter, J. (1912). The Theory of Economic Development. New York, OUP.

Shaw, E. S. (1973). Financial Deepening in Economic Development. New York: Oxford University Press.

Smith. A (1776). Recherches sur la nature et les causes de la richesse des nations », Gallimard (édition 1976), Paris, p. 167 cité dans Saïdane. D (2002): op. cit. p. 6. https://doi.org/10.1522/cla.sif.sma.rec5

William, G. M., \& Nelson, A. G. (1960). Agricultural Finance, The Iowa State University Press, Ames, Iowa.

Yucel, F. (2009). Causal Relationships between Financial Development, Trade Openness and Economic Growth: The case of Turkey. Journal of Social Sciences, 5(1), 33-42. https://doi.org/10.3844/jssp.2009.33.42

Zuberi, H. A. (1989) Production Function, Institutional Credit and Agricultural Development in Pakistan. The Pakistan Development Review, 28(1), 43-56. https://doi.org/10.30541/v28i1pp.43-56

\section{Copyright Disclaimer}

Copyright for this article is retained by the author(s), with first publication rights granted to the journal.

This is an open-access article distributed under the terms and conditions of the Creative Commons Attribution license (http://creativecommons.org/licenses/by/4.0/). 